\title{
EVALUATION OF ANTIULCEROGENIC PROPERTY OF QUERCETIN IN ALBINO RATS
}

Ramesh H, Dattatri A. N, Patil R. S.

1. Associate Professor, Department of Pharmacology, Karnataka Institute of Medical Sciences (KIMS), Hubli.

2. Professor, Department of Pharmacology, Karnataka Institute of Medical Sciences (KIMS), Hubli.

3. Tutor, Department of Pharmacology, Karnataka Institute of Medical Sciences (KIMS), Hubli.

\section{CORRESPONDING AUTHOR}

Dattatri A. N, Professor of Pharmacology,

KIMS, Hubli,

E-mail: an_dattatri@yahoo.com

Ph: 00919902354622.

\begin{abstract}
OBJECTIVES: To study the possible antiulcerogenic property of quercetin, and to compare it with standard drug ranitidine. METHODS: The study was carried out in two ulcer models i.e alcohol model and indomethacin model. Both the models consist of 3 groups (control, standard control, test compound groups) of 6 rats each. The control group received only ulcerogen whereas the standard control group and test compound group were pretreated with ranitidine and quercetin respectively for 5 days before exposure to ulcerogen. On 5 th day the rats were sacrificed, stomach dissected out and opened. Ulcer grading was done and ulcer index was calculated. Statistical analysis was done by using Student's t test. $p$ value of $<0.05$ was considered for statistical significance. RESULTS: In Alcohol model, the rats pretreated with quercetin showed highly significant protection $(p<0.001)$ when compared to control group and significant protection when compared to ranitidine pretreated group ( $p<0.05$ ). In indomethacin model, both quercetin and ranitidine pretreated groups showed significant protection when compared to control group $(\mathrm{p}<0.01)$. CONCLUSION: Present study indicates that quercetin is highly effective in preventing ethanol-induced gastric mucosal damage (better than ranitidine) and equally effective as ranitidine in preventing indomethacin-induced gastric mucosal damage.
\end{abstract}

KEY WORDS: Quercetin, Ranitidine, Gastric ulcer, Ethanol, Indomethacin.

INTRODUCTION: Peptic ulcer is very common disease. It kills few but troubles many ${ }^{1}$. Peptic ulcer results probably due to an imbalance between aggressive factors (acid, pepsin, H. pylori) and defensive factors (gastric mucus, prostaglandins and bicarbonate secretion). ${ }^{2}$. Whatever may be the cause of peptic ulcer, it is the gastric acid that prevents ulcer healing and maintain the ulcer. Therefore most of the drugs available for treatment of peptic ulcer either neutralize the secreted acid or decrease the acid secretion.

There is growing body of experimental data that suggests the generation of oxygen derived free radicals and lipid peroxidation as one of the mechanisms in pathogenesis of peptic ulcer. ${ }^{3}$ Hence there is a need to develop drugs that are directed towards scavenging of these free radicals and produce antiulcerogenic effect.

Quercetin is a bioflavonoid found in many plants. It is widely distributed in edible fruits and vegetables 4 . It is weakly toxic drug and has been used in the treatment of allergy, bee sting and ulcer with no serious side effects in adults ${ }^{5}$. It is a very strong antioxidant, prevents oxidant injury and cell death by several mechanisms such as scavenging oxygen free radicals ${ }^{6,7}$. Its 
antioxidant potential is four times that of vitamin $\mathrm{E}^{8}$. It is potent inhibitor of lipid peroxidation ${ }^{9,10,11}$. It is also a proton pump inhibitor ${ }^{10}$. Because of these properties of quercetin this scientific study is undertaken to evaluate its antiulcerogenic property in albino rats.

MATERIALS AND METHODS: Animals : 36 albino rats of Wistar strain of either sex weighing 150 - 200 g were selected from central animal house of Karnataka Institute of Medical sciences, Hubli. The animals were kept on standard diet and allowed food and water ad libitum. The experimental protocol was approved by the institutional animal ethical committee.

\section{MATERIALS:}

Drugs:

- Ethanol (99.9\%) - As ulcerogenic agent.

- Indomethacin (Microlabs Ltd) - As ulcerogenic agent.

- Ranitidine (JB Chemicals \& Pharmaceuticals Ltd) - As standard control.

- Quercetin (Sisco Research Laboratories) - As test compound.

Dose and duration and administration of drugs

- Ethanol (99.9\%) - A dose of $1 \mathrm{ml}$.

- Indomethacin $-20 \mathrm{mg} / \mathrm{kg}, 2$ doses at an interval of $15 \mathrm{hrs}$.

- Ranitidine $-25 \mathrm{mg} / \mathrm{kg}$, once daily for 5 days.

- Quercetin $-50 \mathrm{mg} / \mathrm{kg}$, once daily for 5 days $^{12}$.

(Quercetin powder freshly dissolved in distilled water during treatment)

All drugs are administered intragastrically through infant feeding tube.

\section{METHODS:}

1) Ethanol induced gastric ulcers

In this method, 18 albino rats were divided into 3 groups with 6 rats in each group.

Group I A (Control) : : Received ulcerogen only.

Group I B (Standard control): Received ranitidine once daily for 4 days and 30 minutes prior to ulcerogen on $5^{\text {th }}$ day

Group I C (Test compound) : Received quercetin once daily for 4 days and 30 minutes prior to ulcerogen on $5^{\text {th }}$ day

The animals in all the groups were fasted for $24 \mathrm{hrs}$ prior to the administration of ulcerogen with water ad libitum.

Animals were sacrificed 4 hrs after the administration of ethanol by dislocating cervicoatlanto joint. The anterior abdominal wall was opened and the stomach was dissected out.

\section{2) Indomethacin induced gastric ulcers}

In this method 18 albino rats were divided into 3 groups of 6 rats each.

Group II A (Control) : Received ulcerogen only.

Group II B (Standard control): Received Ranitidine once daily for 3 days and 30

minutes prior to ulcerogen on $4^{\text {th }} \& 5^{\text {th }}$ day

Group II C (Test compound) : Received quercetin once daily for 3 days and 30 minutes prior to ulcerogen on $4^{\text {th }} \& 5^{\text {th }}$ day. 
The animals in all the groups were fasted for $24 \mathrm{hrs}$ prior to the administration of ulcerogen with water ad libitum. Two doses of indomethacin were administered at an interval of 15 hrs.

Animals were sacrificed $6 \mathrm{hrs}$ after the second dose of indomethacin by dislocating cervico-atlanto joint. The anterior abdominal wall was opened and the stomach was dissected out.

In both the methods, the dissected stomachs were opened along the greater curvature, the number of ulcers was noted and grading of ulcers was done according to the method described by Laurence and Bacharach ${ }^{13}$ :

$\begin{array}{ll}\text { Grade } & \text { Type of gastric mucosa } \\ 0 & \text { Normal } \\ 1 & \text { Scattered hemorrhage spots } \\ 2 & \text { Hemorrhagic spots + ulcer } \\ 3 & \text { Deep hemorrhagic spots + ulcer } \\ 4 & \text { Perforation }\end{array}$

The ulcer index was calculated for each group by the method of Sunita and Devdas ${ }^{14}$ :

Ulcer index $=\begin{aligned} & \text { Arithmetic mean of the } \\ & \text { intensity in a group }\end{aligned}+\left(\begin{array}{l}\text { Ulcer positive No. x 2 } \\ \text { TotalNo. of rats }\end{array}\right)$

Statistical analysis: The results were interpreted by paired Student's $t$ test. A p value of < 0.05 was considered as statistically significant.

RESULTS: Group I A: In this group, the total score, mean score, ulcer incidence and ulcer index were $16,2.67,100 \%$ and 4.6 respectively. (Table 1 )

Group I B: In this group there was reduction in total score, mean score, ulcer incidence and ulcer index as compared to control group. The $p$ value was significant $(p<0.05)$ (Table 1$)$

Group I C: In this group there was reduction in total score, mean score, ulcer incidence and ulcer index. The $p$ value was highly significant compared to control group $(p<0.001)$ and significant as compared to standard control group $(\mathrm{p}<0.05)$. (Table 1 )

Group II A: In this group, the total score, mean score, ulcer incidence and ulcer index were 15, $2.5,100 \%$ and 4.5 respectively. (Table 2 )

Group II B: In this group there was reduction in total score, mean score, ulcer incidence and ulcer index as compared to control group. The p value was significant $(p<0.01)$ (Table 2)

Group II C: In this group there was reduction in total score, mean score, ulcer incidence and ulcer index as compared to control group. The $\mathrm{p}$ value was significant $(\mathrm{p}<0.01)$. But the total score and ulcer index were slightly higher as compared to standard control group, and it was not statistically significant $(\mathrm{p}>0.05)$. (Table 2 )

DISCUSSION: Present study was undertaken to evaluate the protective effect of quercetin against ethanol and indomethacin-induced gastric mucosal damage. 
Ethanol-induced gastric mucosal damage was seen in the glandular portion of stomach as elongated red streak. The fore-stomach or rumen (non-glandular portion) was spared. This may be due to squamous epithelium that covers its surface ${ }^{15}$. The ulcer lesions were confined to the mucosal crests, and this may be due to the presence of these folds at the time of exposure to ethanol16. Ethanol- induced damage to gastric mucosa is associated with a significant production of free radicals ${ }^{17}$, leading to increased lipid peroxidation. This causes damage to cell membranes.

In our study, pretreatment with quercetin in the dose of $50 \mathrm{mg} / \mathrm{kg}$ reduced total score, ulcer incidence and ulcer index as compared to control group (I A). The p value was $<0.001$ (highly significant).

Quercetin is a flavonoid and has potent lipid peroxidation inhibiting property ${ }^{10,11}$. As lipid peroxidation is suggested to be one of the important mechanisms of Ethanol induced gastric ulcer, quercetin probably acts by inhibiting the lipid peroxidation.

Even though ranitidine pretreated animals (I B) showed significant reduction in total score, ulcer incidence and ulcer index as compared to control group (I A) ( $p<0.05$ ), it was inferior when compared to quercetin pretreated group $(\mathrm{p}<0.05)$. This indicates the superiority of quercetin over ranitidine in preventing ethanol-induced gastric mucosal damage.

Ranitidine acts by blocking $\mathrm{H}_{2}$ receptors and thus inhibits gastric acid secretion. Ethanol-induced ulcers occur instantaneously irrespective of the acid content in the stomach. As the mechanism of gastric mucosal damage by ethanol is different, $\mathrm{H}_{2}$ blockers are only partially effective in inhibiting ethanol-induced gastric mucosal damage. This finding correlates with the study conducted by Robert et al ${ }^{15}$.

Normal amount of gastric acid is also necessary for the development of gastric ulcers produced by NSAIDs ${ }^{15}$. In the present study, in indomethacin-induced gastric ulcer model, the total score, ulcer incidence and ulcer index in ranitidine pretreated animals (II B) were significantly reduced as compared to control group (II A) $(\mathrm{p}<0.01)$. As the $\mathrm{H}_{2}$ blockers reduce the gastric acid secretion, they are effective in preventing the gastric mucosal damage produced by NSAIDs. In quercetin pretreated animals (II C) even though the total score, ulcer incidence and ulcer index were significantly reduced when compared to control group $(\mathrm{p}<$ 0.01 ), the total score and ulcer index were only slightly higher as compared to ranitidine pretreated group (statistically not significant; $p>0.05$ ). So the protection given by quercetin against indomethacin-induced gastric mucosal damage is nearly comparable to that by ranitidine.

In a study conducted by Rao CV et al, quercetin significantly decreased the acid and pepsin output of gastric contents ${ }^{11}$. In another study conducted by Elango $\mathrm{V}$ et al, quercetin was shown to inhibit the proton pump and increase the synthesis of local prostaglandins ${ }^{10}$. Thus it appears that quercetin exert its gastric mucosal protection against indomethacin-induced lesions by decreasing acid and pepsin content of the stomach and by increasing local prostaglandin synthesis. In another study, Yoshikawa et al reported the role of active oxygen species and lipid peroxidation in the pathogenesis of gastric mucosal injury induced by indomethacin ${ }^{18}$. As quercetin is a potent inhibitor of lipid peroxidation, it prevents indomethacin-induced gastric mucosal damage.

In our study quercetin has been found to be better than ranitidine in preventing ethanolinduced gastric mucosal damage and nearly equally effective as ranitidine in preventing indomethacin-induced gastric mucosal damage. 
ACKNOWLEDGEMENT: The authors wish to thank Mrs. S. R. Itagimath for statistical help.

\section{REFERENCES:}

1. Laurence DR, Bennet PN, Brown MJ. Clinical Pharmacology. $8^{\text {th }}$ ed. Singapore: Longman Publishers Pvt Ltd; 1997; 567-78.

2. Soll AH. Pathogenesis of peptic ulcer and implications for therapy. N Engl J Med. 1990; 322: 909-16.

3. Desai JK, Goyal RK, Parmar NS. Pathogenesis of peptic ulcer disease and current trends in therapy. Indian J Physiol Pharmacol. 1997; 41(1): 3-15.

4. Suolinna EM, Buchsbaun RN, Racker E. The effect of flavonoids on aerobic glycolysis and growth of tumour cells. Cancer Res. 1975; 35: 1865-72.

5. Havsteen B. Flavonoids, a class of natural products of high pharmacological potency. Biochem Pharmacol. 1983; 32: 1141-8.

6. Bors W, Heller W, Michel C, Saren M. Flavonoids as antioxidants: determination of radical scavenging efficiencies. Methods Enzymol. 1990; 186: 343-55.

7. Park C, So HS, Shin $\mathrm{CH}$ et al. Quercetin protects the hydrogen peroxide induced apoptosis via inhibition of mitochondrial dysfunction in H9c2 cardiomyoblast cells. Biochem Pharmacol. 2003; 66(7): 1287-95

8. Bramley PM. Pridham JB. The relative antioxidant activities of plant derived polyphenolic flavonoids. Free radical Res. 1995; 4: 375-83.

9. Chen ZY, Chan PJ, HO KY, Fung KP, Wang J. Antioxidant activity of natural flavonoids is governed by number and location of their aromatic groups. Chem Phys Lipids. 1996; 79: 157-63.

10. Elango V, Carolin Oliver, Raghu PS. Antiulcer activity of the leaf ethanolic extract of Mimosa pudica in rats. Hygeia J. D. Med. 2012; 4(1): 34-40.

11. Rao CV, Vijaykumar M. Effect of quercetin, flavonoids and alpha tocopherol, an antioxidant vitamin, on experimental reflux oesophagitis in rats. Eur J Pharmacol. 2008; 589(1-3): 233-6.

12. Vidhya A, Indira M. Protective effect of quercetin in the regression of Ethanol induced hepatotoxicity. Indian J Pharm Sci. 2009; 71: 527-32.

13. Laurence DR, Bacharach AL. Evaluation of Drug Activities: Pharmacometrics, Vol $2.1^{\text {st }}$ ed. New York: Academic Press; 1964: 510.

14. Jain Sunita, Santani Devdas. Modification of duodenal ulcer by calcium channel blockers in rats. Ind J Pharmacol. 1996; 28: 167-70.

15. Robert A et al. Cytoprotection by prostaglandins in rats. Gastroenterology. 1979; 77: 433-43.

16. Lacy ER, Ito S. Microscopic analysis of ethanol damage to rat gastric mucosa after treatment with a prostaglandin. Gastroenterology. 1982; 83: 619-25.

17. Istran Szelchji, Kay Brune. Possible role of oxygen free radical in ethanol induced gastric mucosal damage in rats. Dig Dis Sci. 1988;33:865-71

18. Yoshikawa $\mathrm{T}$ et al. Role of active oxygen, lipid peroxidation and antioxidants in the pathogenesis of gastric mucosal injury induced by Indomethacin in rats. Gut. 1993; 34: 732-7. 
Table 1 Ethanol-induced gastric ulcers

\begin{tabular}{|l|l|l|l|}
\hline & $\begin{array}{l}\text { Group I A } \\
\text { (Control group) }\end{array}$ & $\begin{array}{l}\text { Group I B } \\
\text { (Standard control group) } \\
* *\end{array}$ & $\begin{array}{l}\text { Group I C } \\
\text { (Test compound group) } \\
* * *\end{array}$ \\
\hline Total score & 16 & 12 & 4 \\
\hline Mean score & 2.67 & 2.0 & 0.67 \\
\hline $\begin{array}{l}\text { Total No. of rats with } \\
\text { ulcer }\end{array}$ & 6 & 4 & 1 \\
\hline Ulcer incidence & $100 \%$ & $66.66 \%$ & $16.66 \%$ \\
\hline Ulcer index & 4.6 & 3.3 & 1 \\
\hline Standard deviation & 0.516 & 0.894 & 0.816 \\
\hline
\end{tabular}

$* \mathrm{p}<0.001$ when I C is compared to I A

** $\mathrm{p}<0.05$ when I B is compared to I A \& I C is compared to I B

Table 2 Indomethacin-induced gastric ulcers

\begin{tabular}{|l|l|l|l|}
\hline & $\begin{array}{c}\text { Group II A } \\
\text { (Control group) }\end{array}$ & $\begin{array}{l}\text { Group II B } \\
\text { (Standard control group) } \\
*\end{array}$ & $\begin{array}{l}\text { Group II C } \\
\text { (Test compound group) } \\
*\end{array}$ \\
\hline Total score & 15 & 6 & 8 \\
\hline Mean score & 2.5 & 01 & 1.33 \\
\hline $\begin{array}{l}\text { Total no of rats with } \\
\text { ulcer }\end{array}$ & 6 & 2 & 2 \\
\hline Ulcer incidence & $100 \%$ & $33.33 \%$ & $33.33 \%$ \\
\hline Ulcer index & 4.5 & 1.6 & 1.9 \\
\hline Standard deviation & 0.548 & 0.814 & 0.516 \\
\hline
\end{tabular}

$* \mathrm{p}<0.01$ When II B is compared to II A \& II C is compared to II A 